\title{
Tatakelola Anestesi untuk Dekompresi Kraniektomi pada Cedera Otak Traumatik Berat dengan Penyulit Obesitas Morbid
}

\author{
Fitri Sepviyanti Sumardi*), Iwan Abdul Rachman**), Bambang J. Oetoro ${ }^{* * *}$ ) \\ ${ }^{*}$ Departemen Anestesiologi dan Terapi Intensif Henan Provincial People's Hospital International Center for \\ Neurosurgery dan Henan Cerebrovascular Disease Hospital-Afiliasi Zhengzhou University-China, ${ }^{* *}$ Departemen \\ Anestesiologi dan Terapi Intensif Fakultas Kedokteran Universitas Padjadjaran-RSUP. Dr. Hasan Sadikin Bandung, \\ ${ }^{* * *}$ Departemen Anestesiologi dan Terapi Intensif Mayapada Hospital Group Tahir Neuroscience Center Jakarta
}

\begin{abstract}
Abstrak
Anestesi dan pembedahan menyebabkan risiko yang cukup besar untuk pasien obesitas, apalagi obesitas morbid. Populasi orang gemuk meningkat, baik di negara maju dan berkembang, sehingga para ahli anestesi lebih sering menghadapi tantangan dalam mengelola pasien obesitas. Trauma multipel bertanggung jawab atas 5 juta kematian per tahun di seluruh dunia dan merupakan penyebab kematian utama bagi orang muda di bawah 40 tahun, mewakili peristiwa akut dan tak terduga. Kami akan melaporkan seorang lelaki 36 tahun dengan obesitas morbid, BMI 48,97 kg/m2, yang mengalami trauma multipel akibat kecelakaan lalulintas, yang akan menjalani operasi evakuasi perdarahan subdural dan dekompresi kraniektomi. Pemilihan obat dan dosis aman sangat sulit pada pasien dengan trauma multipel, karena mungkin status volumenya tidak diketahui secara akurat. Rencana anestesi harus mempertimbangkan status resusitasi dan riwayat penyakit penyerta lain. Peran penting lainnya dari ahli anestesi adalah pencegahan cedera sekunder yang disebabkan oleh syok berulang atau resusitasi tidak tepat.
\end{abstract}

Kata kunci: Anesthesia cedera otak traumatik; dekompresi kraniektomi; obesitas morbid

JNI 2020; 9 (1): 33-44

\section{Anesthesia Management for Craniectomy Decompression on Severe Traumatic Brain Injury with Comorbid Morbid Obesity}

\begin{abstract}
Anesthesia and surgery may bring considerable risk for obese patients, especially morbid obesity. Obese populations increase, both in developed and developing countries, so anesthesiologists more often face challenges in managing obese patients. Multiple traumas is responsible for 5 million deaths per year worldwide and is the leading cause of death for young people under 40, representing acute and unexpected events. We will report a 36-year-old man with morbid obesity, a BMI of $48.97 \mathrm{~kg} / \mathrm{m} 2$, who experienced multiple traumas due to traffic accident, who underwent an evacuation operation for subdural hemorrhage and craniectomy decompression. The selection of drugs and safe doses is very difficult in patients with multiple traumas, because their volume status may not be accurately known. Anesthetic plan must consider resuscitation status and other comorbidities. Another important role of anesthesiologist is the prevention of secondary injury caused by recurrent shock or improper resuscitation.
\end{abstract}

Key words: Anesthesia; brain surgery; morbid obesity; multiple trauma

JNI 2020; 9 (1): 33-44 


\section{Pendahuluan}

Populasi orang gemuk meningkat, baik negara maju dan berkembang, sehingga para ahli anestesi lebih sering menghadapi tantangan dalam mengelola pasien obesitas. ${ }^{1}$ Kata obesitas berasal dari kata latin 'obesus' yang berarti pemaparan makan. Ini adalah kondisi di mana lemak tubuh berlebih. ${ }^{2}$ Metode yang paling umum digunakan untuk mengukur obesitas adalah indeks massa tubuh body mass index (BMI):

\section{$\mathrm{BMI}=$ berat badan/ tinggi badan ${ }^{2}\left(\mathrm{~kg} / \mathrm{m}^{2}\right)$}

BMI $<25 \mathrm{~kg} / \mathrm{m}^{2}$ dianggap normal, seseorang dengan BMI $25-30 \mathrm{~kg} / \mathrm{m}^{2}$ dianggap kelebihan berat badan tetapi berisiko rendah komplikasi medis serius, sementara mereka dengan $\mathrm{BMI}>30$, $>35$ dan $>55 \mathrm{~kg} / \mathrm{m}^{2}$ dianggap obesitas dan super obesitas/obesitas morbid tidak sehat. Meskipun BMI adalah alat yang paling umum digunakan untuk menilai tingkat keparahan obesitas, itu belum tentu prediktor klinis terbaik dari penyakit. Distribusi jaringan adiposa daripada berat absolut atau BMI tampaknya lebih relevan secara klinis. Obesitas android yang distribusi lemak truncal dikaitkan dengan tingginya insiden gangguan kardiovaskular dan obesitas ginekoid di mana lemak didistribusikan ke paha dan pantat tidak terkait dengan masalah kardiovaskular. ${ }^{1-2}$

Trauma multipel bertanggung jawab atas 5 juta kematian pertahun diseluruh dunia danmerupakan penyebab kematian utama bagi orang-orang muda di bawah 40 tahun, mewakili peristiwa akut dan tak terduga. ${ }^{3}$ Di antara penyebab kematian karena trauma, kecelakaan akibat menggunakan motor merupakan hal tersering, sering terhitung sebanyak $70 \%$ menyebabkan kematian. ${ }^{3}$ Kematian akibat trauma terjadi di tiga puncak pada skala waktu. Trauma terfatal seperti misalnya transeksi aorta menimbulkan puncak pertama terjadi dalam hitungan detik hingga menit dari insiden kejadian. ${ }^{4}$ Puncak kedua berikutnya bisa terjadi dalam beberapa jam, mungkin disebabkan oleh hemopneumothorax dan kehilangan darah yang signifikan akibat trauma multipel. ${ }^{4}$ Puncak ketiga biasanya disebabkan oleh sepsis dan beberapa disfungsi organ, terjadi beberapa hari hingga minggu setelah kejadian. ${ }^{4}$ Anestesi untuk trauma multipel adalah salah satu tantangan tertinggi bagi para ahli anestesi, karena para ahli anestesi harus menangani pasien dalam keadaan kritis dengan riwayat dan status fisiologis yang tidak jelas yang disertai cedera. Diagnosis bedah biasanya tidak diketahui secara pasti pada saat sayatan, seperti prosedur operasi apa yang dilakukan. Para ahli anestesi sering tidak punya waktu untuk menempatkan monitor invasif yang diinginkan dan jarang punya waktu untuk melakukan resusitasi volume lengkap. Namun demikian, para ahli anestesi harus tetap membius, melumpuhkan, memantau, dan menyadarkan pasien-pasien ini, sementara ahli bedah mencari sumber dan mengontrol atau menghentikan perdarahan terjadi, bila diperlukan melakukan reseksi pada organ yang terluka. ${ }^{3-4}$ Laporan kasus di bawah ini mengenai bagaimana pertimbangan kami, sebagai dokter anestesi mengelola pasien dengan obesitas morbid yang mengalami trauma multipel akibat kecelakaan lalu lintas.

\section{Kasus}

\section{Anamnesis}

Seorang lelaki 36 tahun dengan diagnosis cedera kepala berat disertai dengan kontusio paru, fraktur tertutup klavikula kiri dan fraktur tertutup 1/3 tibia fibula, berat badan $150 \mathrm{~kg}$ dan tinggi badan $175 \mathrm{~cm}$, BMI 48,97 kg/m² datang ke RS. Mayapada, Jakarta. Pasien mengalami kecelakaan lalu lintas 1 hari sebelum masuk rumah sakit. Pasien dirujuk dari rumah sakit lain dengan keadaan sudah terintubasi dengan ETT no 7,5 kedalaman $22 \mathrm{~cm}$ dan di bawah pengaruh obat propofol kontinyu. Riwayat penyakit dahulu hipertensi, tidak terkontrol. Tidak ada riwayat kejang, muntah, keluar darah dari telinga/hidung, perdarahan di sekitar mata, konsumsi obatobatan, demam, diabetes mellitus dan penyakit penyerta lainnya.

\section{Pemeriksaan Fisik}

Pada pemeriksaan fisik ditemukan keadaan pasien: glasgow coma scale (GCS) sulit ditentukan karena di bawah pengaruh obat propofol kontinyu, pupil bulat isokor, reflex 
cahaya $+/+$, hemiparesis anggota badan kanan motorik $4 / 5$, tekanan darah $167 / 93 \mathrm{mmHg}$, laju nadi $99 \mathrm{x} /$ menit, laju napas $24-27 \mathrm{x} /$ menit, suhu $36,5^{\circ} \mathrm{C}$. Tampak jejas di dada atas dan perut. Tampak deformitas pada klavikula dan kaki kiri. Pemeriksaan paru auskultasi VBS \pm melemah $/+$, rochi $+/-$, wheezing $-/-$, bunyi jantung kanan=kiri, tidak terdapat murmur.

\section{Pemeriksaan Penunjang}

Pemeriksaan laboratorium darah menunjukkan $\mathrm{Hb}$ 16,2 g/dL; Ht 45\%; Leukosit $16500 / \mu \mathrm{L}$; Trombosit $224 \mathrm{ribu} / \mu \mathrm{L} ; \mathrm{PT} 10,3$ detik; INR 0,76; APTT 24,1 detik; Fibrinogen $482 \mathrm{mg} / \mathrm{dL}$, D-Dimer 1,81; Analisis Gas Darah: 7,518/39,9/95/32,6/9,6/97,7 dengan $\mathrm{O}_{2} 100 \%$. Hasil lain dalam batas normal. Pada pemeriksaan CT-scan: SDH, SAH, herniasi subfalcine ke kanan. Tampak sedikit pergeseran garis tengah (Gambar 1) Tampak fraktur komplit diafisis distal pada klavikula kiri. (Gambar 2)

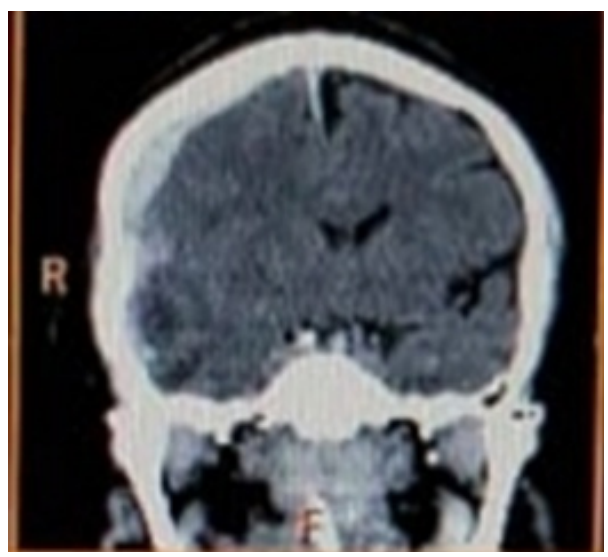

Gambar 1. Foto CT-Scan Kepala

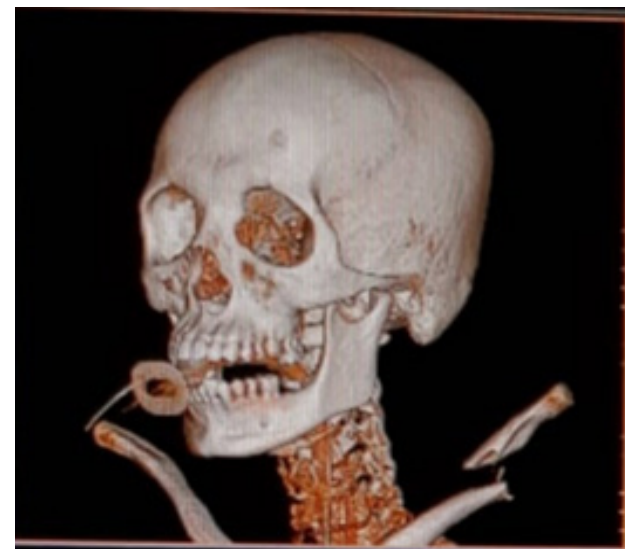

Gambar 2. Foto CT-Scan Kepala-Leher
Pada pemeriksaan foto toraks: Tampak perselubungan dengan gambaran air bronchogram memenuhi lobus superior paru kanan. Tidak tampak kelainan radiologis pada jantung, CTR < $60 \%$. Tampak fraktur komplit diafisis distal pada klavikula kiri.(Gambar 3). Pemeriksaan ECHO: EF $70 \%$, Left ventricle hypertrophy (LVH) (-), Aorta Valve (AV) normal, Mitral valve/MV normal. Pada pemeriksaan foto ekstremitas kiri bawah: Tampak fraktur tertutup $1 / 3$ distal tibia fibula.

\section{Penatalaksanaan Anestesi}

Pasien dibawa ke kamar operasi, pasien diposisikan kepala lebih tinggi 300 dan dipasang tensimeter, chest piece EKG dan pulse oxymetri. Endotracheal tube disambungkan dengan mesin ventilator anestesi. Dilakukan induksi anestesi umum dengan prinsip proteksi otak melalui kombinasi pemberian fentanyl $150 \mu \mathrm{g}$ titrasi, propofol $100 \mathrm{mg}$ titrasi, vecuronium $8 \mathrm{mg}$.

Rumatan anestesi: diberikan sevoflurane $0,8-1$ vol\% dengan aliran oksigen dan air (50:50) kombinasi syringe kontinyu: vecurronium $2 \mathrm{mg} /$ jam dan propofol $50-100 \mathrm{mg} / \mathrm{jam}$, tergantung hemodinamik pasien selama operasi. Dipasang central venous catheter 3 lumen di vena subclavia kanan Dilakukan operasi evakuasi perdarahan, sebelum dura dibuka diberikan manitol 20\% 0,5 $\mathrm{gr} / \mathrm{KgBB}$. Total cairan yang masuk ringerfundin $1500 \mathrm{cc}$ dan gelofusine $500 \mathrm{cc}$, perdarahan \pm 200

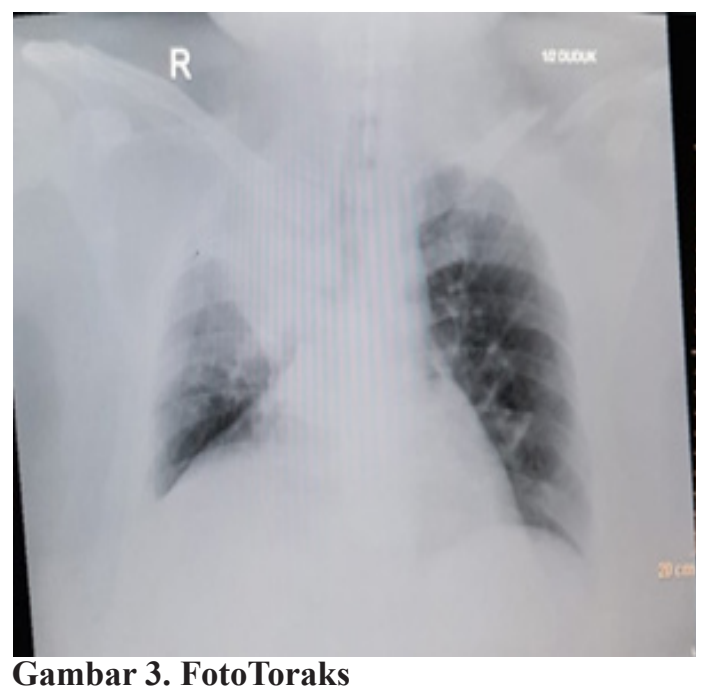




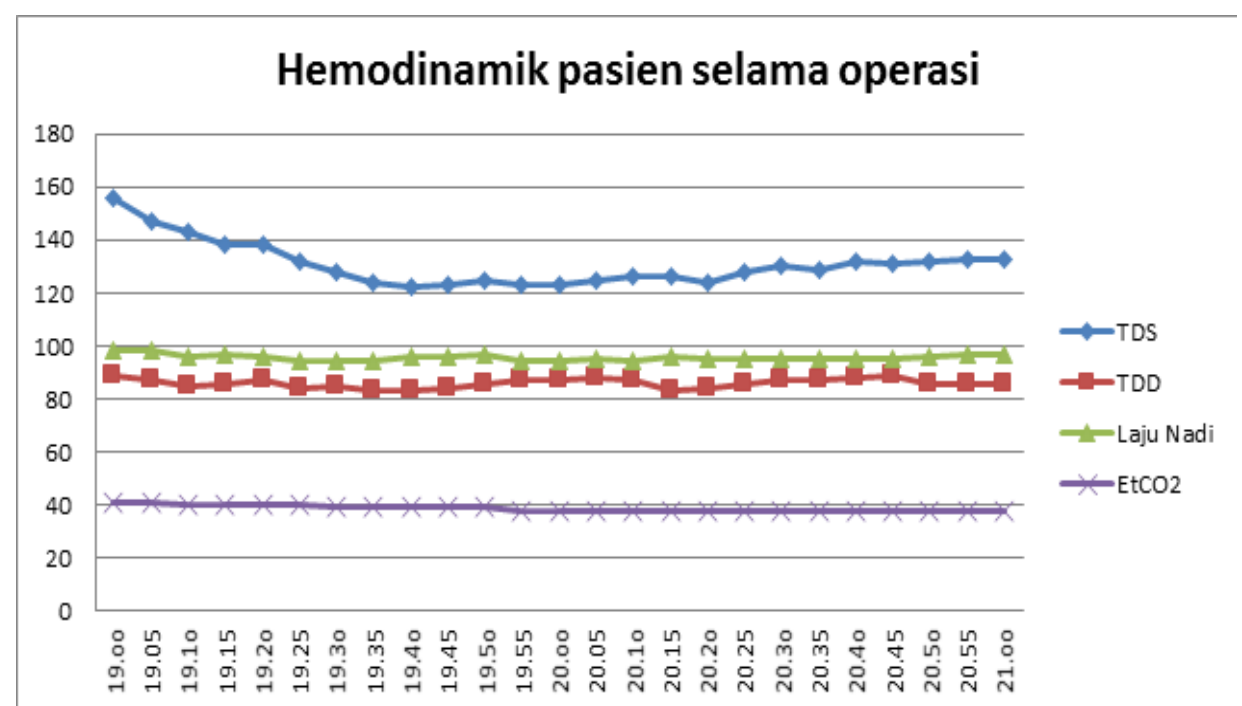

Gambar 2. Keadaan Hemodinamik Pasien saat Operasi

Keterangan: TDS: tekanan darah sistolik; TDD: tekanan darah diastolic; $\mathrm{Et}_{\mathrm{CO}_{2}}$ : End Tidal $\mathrm{CO}_{2}$

Tabel 1. Abbreviated Injury Scale (AIS) ${ }^{4}$

\begin{tabular}{ll}
\hline AIS & Derajat Trauma \\
\hline 1 & Ringan \\
2 & Sedang \\
3 & Serius \\
4 & Berat \\
5 & Kritis \\
6 & Tidak selamat \\
\hline
\end{tabular}

Tabel 2. Injury Severity Score (ISS) ${ }^{4}$

\begin{tabular}{ll}
\hline AIS & Derajat Trauma \\
\hline $1-8$ & Ringan \\
$9-15$ & Sedang \\
$16-24$ & Serius \\
$25-49$ & Berat \\
$50-74$ & Kritis \\
75 & Maksimal \\
\hline
\end{tabular}

Tabel 3. Penilaian AIS dan ISS pasien saat datang ke unit gawat darurat Rumah Sakit Mayapada

\begin{tabular}{llll}
\hline Regio/Area & Gambaran Trauma & AIS & Tiga Masalah Teratas \\
\hline Kepala dan leher & Cedera kepala berat & 4 & 16 \\
Wajah & Tampak luka-luka lecet & 1 & \\
Perut & Kontusio ringan & 2 & 4 \\
Ekstremitas & $\begin{array}{l}\text { fraktur 1/3 distal tertutup } \\
\text { tertutup }\end{array}$ & 1 & 1 \\
Faktor eksternal & Tidak ada luka & 0 & \\
& ISS & & 21 \\
\hline
\end{tabular}

cc, jumlah urin yang keluar $2000 \mathrm{cc}$. Lama operasi 2 jam 15 menit dan lama pasien teranestesi 2 jam 30 menit. Tekanan darah selama operasi $122 / 83$ $-195 / 102 \mathrm{mmHg}$ dan laju nadi $94-102 \mathrm{x} /$ menit. Penilaian status neurologis pascabedah sulit dinilai, karena masih di bawah pengaruh obatobatan anestesi. Bedah ortopedi memutuskan pemasangan gips pada fraktur tertutup $1 / 3$ distal tibia fibula kiri, pada saat yang bersamaan dan tindakan konservatif untuk fraktur tertutup klavikula kiri.(Gambar 2)

Penatalaksanaan Pascabedah di ICU

Pasien dipindahkan ke ruangan intensive care unit (ICU) masih terintubasi, kemudian disambungkan dengan mode ventilator: SIMV PS 10 TV 500 RR 
12 PEEP $5 \mathrm{FiO}_{2}$ 50-100 \% (sesuai $\mathrm{SpO}_{2}$ ). Skor GCS sulit dinilai (masih di bawah pengaruh obat anestesi), tekanan darah $138 / 98 \mathrm{mmHg}$, laju nadi $98 \mathrm{x} / \mathrm{menit}$, laju napas $12 \mathrm{x} / \mathrm{menit}, \mathrm{SaO}_{2} 100 \%$. Untuk analgetik pascabedah diberikan morfin 10 mg+fentanyl $200 \mu \mathrm{g}+$ metoclopramide $10 \mathrm{mg}+$ ondansentron $8 \mathrm{mg}$ yang dicampur dalam syringe pump, dijalankan $5 \mathrm{ml} / \mathrm{jam}$. Pasien disedasi dengan propofol kontinyu $50-100 \mathrm{mg} / \mathrm{jam}$ (sesuai keadaan hemodinamik). Laboratorium pascabedah menunjukkan: 13,2 g/dL; Ht $37 \mathrm{~g} /$ dL; Leukosit $21800 / \mu \mathrm{L}$; Trombosit $274 \mathrm{ribu} /$ $\mu \mathrm{L}$; BUN $32 \mathrm{mg} / \mathrm{dL}$; Kreatinin 0,85 mg/dL; GDS $114 \mathrm{mg} / \mathrm{dL}$; Natrium $148 \mathrm{mmol} / \mathrm{L}$; Kalium 3,6 $\mathrm{mmol} / \mathrm{L}$, Klorida $103 \mathrm{mmol} / \mathrm{L}$. Pasien dirawat di ICU selama 5 hari, lalu dipindahkan ke ruang HCU selama 6 hari. Lalu pasien dipindahkan ke ruang rawat inap dan pulang ke rumah pada hari ke-15 perawatan.

\section{Pembahasan}

Anestesi dan pembedahan mungkin meyebabkan risiko yang cukup besar untuk pasien obesitas, apalagi obesitas morbid.8 Obesitas adalah gangguan multi-sistem, terutama yang melibatkan sistem pernapasan dan kardiovaskular; oleh karenaitu, diperlukan pendekatan multidisipliner. ${ }^{8}$ Orang gemuk memiliki pengeluaran energi yang lebih besar daripada orang kurus, dan ini diimbangi dengan asupan kalori yang meningkat. Tingkat metabolisme basal adalah 'normal' pada individu obesitas ketika dikoreksi untuk luas permukaan tubuh. Namun, dengan bertambahnya berat badan, luas permukaan tubuh meningkat dan karenanya nilai-nilai tingkat metabolisme basal mutlak lebih tinggi daripada pada orang kurus. Akibatnya, ada konsumsi oksigen absolut yang lebih besar dan produksi karbondioksida. ${ }^{7-10}$

Penyebab Kegemukan

Penyebab obesitas bersifat multifaktorial termasuk komponen genetik dan lingkungan yang belum diketahui secara pasti. Pengeluaran energi basal meningkat, tetapi ini ditimbali oleh konsumsi kalori yang meningkat secara dramatis. Pengaturan nafsu makan dan kenyang adalah proses yang kompleks di bawah kendali berbagai mekanisme humoral dan neurologis yang terintegrasi, semua berpusat di hipotalamus. ${ }^{7-10}$ Hormon termasuk leptin, adiponektin, insulin, ghrelin dan peptida YY3-36. Leptin dan adiponektin diproduksi oleh adiposit, dan tingkat mereka mewakili massa adiposit total. Leptin memberi sinyal kenyang dan penting dalam mengurangi perilaku makan. Pasien obesitas telah meningkatkan konsentrasi leptin plasma, tetapi sering menunjukkan ketidaksensitifan leptin. Selain itu, diet yang kuat menghasilkan penurunan massa adiposit dengan penurunan tingkat leptin terkait, yang dengan sendirinya dapat menyebabkan peningkatan nafsu makan dan perilaku pola makan. Adiponektin memiliki peran pensinyalan yang serupa dengan leptin, tetapi konsentrasi tidak meningkat pada obesitas. Leptin dan adiponektin mengatur perubahan jangka panjang pada nafsu makan, sedangkan efek jangka pendek ditandai oleh insulin yang bekerja pada hipotalamus. . $^{1-2,7-10}$

Rasa kenyang juga ditandai oleh sekelompok peptida, termasuk ghrelin yang dilepaskan oleh dinding lambung. Makan menyebabkan dinding perut membentang, menekan produksi ghrelin dan mengurangi rasa lapar. Ghrelin juga dianggap terlibat dalam regulasi sensitivitas insulin. Ketika makanan kemudian masuk ke usus kecil, peptida YY3-36 dan peptida terkait dilepaskan, menandakan kenyang. Pengaturan akhir dari keseimbangan energi dan refleks nafsu makan dimediasi melalui sistem saraf otonom. ${ }^{1-2,7-10}$

\section{Komorbiditas}

Obesitas dikaitkan dengan hipertensi, dislipidemia, penyakit jantung iskemik, diabetes mellitus, osteoartritis, penyakit hati dan asma. Obstructive sleep apnea (OSA) adalah masalah umum pada obesitas tidak sehat. Sindrom obesitashipoventilasi sangatjarang terdiagnosis. Kedua hal ini sulit dibedakan, walaupun keduanya berbeda secara klinis. BMI sendiri adalah prediktor yang buruk dari komorbiditas, bedah, atau kesulitan anestesi. ${ }^{1-2,}$, 710 Pengukuran distribusi lemak lingkar pinggang atau leher lebih prediktif dan seringkali lebih bermanfaat dari komorbiditas kardiorespirasi daripada BMI. Distribusi android membuat operasi intra-abdomen lebih sulit dan 
berhubungan dengan penumpukan lemak yang meningkat di sekitar leher dan saluran napas (maka lebih banyak kesulitan dalam manajemen saluran napas dan ventilasi paru-paru). Selain itu, distribusi lemak android dikaitkan dengan risiko komplikasi metabolik dan kardiovaskular yang lebih besar. ${ }^{1-2,7-10}$ Risiko kardiorespirasi dan komorbiditas lainnya meningkat dengan durasi obesitas (penumpukan lemak selama bertahun-tahun). Keberadaan dan keparahan komorbiditas mungkin ditutupi oleh gaya hidup sehat pasien. Pada kenyataannya, banyak penyakit terkait obesitas mungkin hanya muncul selama pemeriksaan pra operasi atau periode perioperatif. ${ }^{1,2,-10}$ Pada kasus kami, pasien menderita obesitas morbid yang disertai riwayat hipertensi tidak terkontrol yang tidak jelas. Pemeriksaan foto toraks dan ECHO menunjukkan masih dalam batas normal.

\section{Penilaian Pra Operasi}

Tujuan dari penilaian pra operasi adalah untuk mengoptimalkan hasil pasien. Ini memungkinkan identifikasi tepat waktu dan perawatan kondisi medis yang sudah ada sebelumnya serta menentukan bagaimana setiap pasien harus dikelola perioperatif. Semua pasien harus dicatat berat badan, tinggi badan dan BMI. Pasien obesitas disertai dengan komorbiditas merupakan resiko tinggi dan perlu perhatian khusus, misalnya: hipertensi, dislipidemia, penyakit jantung iskemik, diabetes melitus, osteoartritis dan penyakit hati. Penurunan berat badan, latihan olahraga dan pengobatan apnea tidur obstruktif sebelum dilakukan tindakan pembedahan dapat menurunkan resiko anestesi dan stres akibat operasi. ${ }^{3-6} \mathrm{Hal}-\mathrm{hal}$ ini mungkin sulit pada pasienpasien yang datang dengan kegawatdaruratan medis yang memerlukan tindakan pembedahan segera, seperti pada pasien kami.

\section{Trauma Multipel dan Cedera Kepala}

Trauma multipel adalah sindrom diakibatkan dari suatu benturan aksi kekuatan berbeda, baik secara mekanik atau kimia yang mempengaruhi setidaknya dua wilayah tubuh manusia, dengan setidaknya satu dari trauma memiliki potensi mematikan. Definisi yang lebih baru dari trauma multipel menyiratkan penggunaan Abbreviated Injury Scale (AIS) (Tabel 1) dan Injury Severity Score (ISS) ( Tabel 2). ISS didasarkan pada AIS dengan skala numerik dari 1-6 (cedera ringan hingga berat). AIS membagi derajat trauma berdasarkan enam wilayah tubuh (Tabel 1) untuk menghitung ISS (Tabel 2): tiga nomor AIS teratas dikuadratkan dan jumlah mereka diambil sebagai ISS.

\section{Regio/Area Gambaran Trauma AIS}

Kontusio paru dapat terjadi akibat penetrasi dan kondisi deselerasi cepat. Fraktur tulang rusuk ditemukan pada 50\% kasus seperti itu. CXR awal tidak membantu dan CT Scan toraks diperlukan untuk mengetahui sejauh mana. Mungkin ada penurunan aprogresif dari komplien paru, sehingga terjadi penurunan $\mathrm{PaO}_{2}$ dan peningkatan edema alveolar. $\mathrm{PaO}_{2} / \mathrm{FiO}_{2}<250$ adalah indikator terbaik untuk hasil yang buruk. ${ }^{11-14}$ Fase edema harus diobati dengan penerapan PEEP, diuretik dan administrasi cairan terkontrol. Koloid versus infus kristaloid bukan merupakan masalah penting karena terjadinya edematous pada area tersebut akibat dari karakteristik paru yang terganggu. Laserasi pulmonal jarang terjadi dengan trauma tumpul di dada, tetapi geseran tumpul atau ujung tulang iga yang patah dapat menjadi penyebab hal ini. ${ }^{16-18}$

\section{$\mathrm{A}=$ Airway $=$ Jalan Napas}

Evaluasi awal dan resusitasi pasien dengan trauma di bagian gawat darurat secara tradisional mengikuti pendekatan "ABCD '- penilaian saluran napas, pernapasan, sirkulasi, dan cacat neurologis berat. $^{3-6,}$ 11-18 Fungsi pernafasan dasar harus ditetapkan dari riwayat pasien dan pemeriksaan fisik. Oksimetri portabel dengan laju nadi mungkin menjadi alat monitoring yang berguna lebih lanjut. Supine arterial oxygen saturation $\left(\mathrm{SpO}_{2}\right)<96 \%$ pada udara ruangan memerlukan pemeriksaan lebih lanjut (spirometri, analisis gas darah arteri) untuk hasil yang lebih tepat. ${ }^{3-6,11-18}$ Indikasi untuk intubasi endotrakeal segera pada pasien trauma adalah sebagai berikut ${ }^{4}$ : cedera kepala dengan GCS $<10$; ketidakstabilan hemodinamik yang parah; obstruksi jalan nafas; pasien kombinasi yang membutuhkan sedasi atau 
analgesia; anestesi umum; trauma dada dengan hipoventilasi (dada anterior flail $>8$ iga); tandatanda kegagalan pernapasan: apnea $>2-3 \mathrm{mnt}$, tingkat pernapasan $<10$ atau $>29 / \mathrm{mnt}, \mathrm{PaO}_{2}<60$ $\mathrm{mmHg}$ dan $\mathrm{PaCO}_{2}>55 \mathrm{mmHg}$.

Jalan napas selalu bebas sepanjang waktu. ${ }^{15}$ Dalam kasus kami, pasien obesitas morbid memiliki GCS 8-9 disertai trauma multipel, terutama terdapat trauma tumpul toraks/kontusio paru. Hal ini menunjukkan bahwa pasien perlu dilakukan intubasi untuk melindungi jalan napas dan/ atau untuk membantu mempertahankan $\mathrm{pH} .{ }^{11-18}$ Pada awalnya, ventilator harus disesuaikan untuk menjaga alkalosis pernafasan ringan (yaitu, $\mathrm{PCO}_{2}$ 33-35 mmHg) untuk membantu menurunkan tekanan intrakranial. Hal terpenting, obat anestesi sedasi dan analgesik harus diberikan secara empiris baik untuk mengobati rasa sakit, mengurangi penderitaan pasien serta meminimalkan lonjakan katekolamin, sehingga tidak terjadi peningkatan tekanan intrakranial yang berhubungan dengan rasa sakit. ${ }^{11-18}$

\section{$\mathrm{B}=$ Breathing $=$ Pernapasan}

Ventilasi kendali untuk mendapatkan oksigenasi adekuat dan sedikit hipokarbia pada tumor otak dan normokarbia pada pasien dengan cedera kepala traumatik. ${ }^{15}$ Trauma toraks tumpul, termasuk memar paru-paru, fraktur tulang rusuk dan dada pecah, menyumbang hampir $25 \%$ mortalitas sekunder akibat trauma tumpul. Resusitasi cairan yang berlebihan (terutama berbasis kristaloid), kegagalan pegelolaan pernapasan, komplikasi operasi dan kontrol nyeri tidak memadai, sehingga pasien tidak dapat diekstubasi dan perburuk kondisi paru. Faktorfaktor tersebut merupakan penyebab kematian setelah trauma dinding dada dan cedera paru berat yang masih kontroversial. ${ }^{16-18}$ Kontusio paru biasanya terjadi pada akibat trauma dengan kekuatan besar, kebanyakan tabrakan kendaraan bermotor, sering berhubungan dengan kelainan dinding dada yang kompleks. Tantangan pengelolaan pasien seperti ini terutama akibat efek fisiologis lokal dan sistemik yang kompleks dari trauma ini. Hal-hal tersebut mengakibatkan penurunan ventilasi sekunder akibat komplien paru yang buruk, peningkatan resistensi pembuluh darah paru, penurunan difusi oksigen dan efek inflamasi lokal dan sistemik. ${ }^{16-18}$ Secara tradisional, ventilasi mekanis telah digunakan secara agresif pada pasien dengan trauma toraks. Namun praktik yang direkomendasikan saat ini adalah ventilasi selektif hanya untuk memperbaiki cacat yang signifikan dalam pertukaran gas. Tidak ada rekomendasi yang jelas mengenai mode ventilator yang paling optimal pada pasien-pasien seperti ini, tetapi umumnya ditegaskan bahwa tekanan endexpiratory positif atau tekanan udara positif yang terus menerus harus dimasukkan dalam pengaturan ventilator pasien dan ekstubasi sedini mungkin. Jika pasien yang mengalami sindrom gangguan pernapasan akut (acute respiratory distress syndrome/ARDS) dapat dilakukan pengaturan ventilator rendah peregangan dan tekanan rendah.

Meskipun beberapa pusat menggunakan ventilasi pelepasan tekanan udara, tidak ada bukti yang meyakinkan bahwa mode ini sama atau lebih unggul dari strategi yang disebutkan di atas dalam hal penurunan angka kematian. ${ }^{13-14,16-18}$ Hal-hal tersebut di atas yang menjadi pertimbangan bagi kami untuk tidak melakukan ekstubasi pada pasien ini dengan segera dan melanjutkan penggunaan ventilator di ICU. Pemeriksaan analisis gas darah, $\mathrm{PaCO}_{2}$ dipertahankan dalam rentang normal (35-45 $\mathrm{mmHg}$ ) sebagai patokan, sampai pasien sadar penuh dan dapat dilakukan ekstubasi.

\section{$\mathrm{C}=$ Circulation $=$ Sirkulasi}

Manajemen cairan pada pasien dengan memar paru membutuhkan perawatan euvolemia dan menghindari hipervolemia. Seperti pada pasienpasien sakit kritis lainnya, penilaian status volume dalam pasien ini dapat menjadi tantangan, dan penulis mendukung pendekatan multimodal untuk masalah ini. Pemeriksaan fisik, output urin, rontgen dada, panel metabolik dasar, konsentrasi hemoglobin, laktat serum, saturasi oksigen vena campuran, dan pengukuran variasi denyut nadi harus digunakan dalam kombinasi untuk menilai status volume intravaskular sebaik mungkin. ${ }^{3-6,16-18}$

Penilaian pra operasi memfasilitasi evaluasi menyeluruh risiko jantung dan pelaksanaan tindakan medis bila memungkinkan, untuk 
meminimalkan risiko. Fungsi jantung bisa sulit untuk memastikan pada pasien kami dari riwayat klinis, karena pasien datang sudah dalam keadaan terintubasi dan di bawah pengaruh obat, tetapi pasien harus menjalani pemeriksaan kardiovaskular mendetail dan teliti. Hal utama mencari bukti adanya hipertensi (dengan ukuran cuff BP yang tepat) dan gagal jantung. Elektrokardiografi (ECG) adalah wajib sebelum operasi. Echocardioraphy dapat memberikan informasi yang berguna tentang status jantung pasien. ${ }^{11-14}$ Pemilihan obat dan dosis aman sangat sulit pada pasien dengan trauma multipel, karena mungkin status volumenya tidak diketahui secara akurat. Meskipun banyak faktor-faktor yang mempengaruhi pilihan obat-obatan untuk induksi dan pemeliharaan anestesi pada pasien dengan trauma multipel, yang paling penting biasanya adalah status volume. ${ }^{13-14} \mathrm{Hal}$ inilah yang menjadi pertimbangan kami untuk memasang CVC pada pasien ini, sehingga kami dapat mengetahui status volume dari CVP, dipertahankan $\pm 8-12 \mathrm{mmHg}$.

Eksaserbasi hipotensi seharusnya tidak menjadi kontraindikasi untuk anestesi, namun, hanya tanda bahwa itu harus digunakan dengan hati-hati. Anestesi yang dalam membuatnya lebih mudah untuk menilai status volume cairan pasien selama pengingat resusitasi karena hipovolemia akan menyebabkan penurunan tekanan darah segera pada pasien di mana pelepasan katekolamin telah diblokir. ${ }^{13-14}$ Hindarilonjakan tekanan darah karena bisa memperberat edema serebral dan kenaikan intracranial pressure (ICP), hindari faktor-faktor mekanis yang meningkatakan tekanan vena serebral, target: normovolemia, normotensi, isoosmoler dan normoglikemia. ${ }^{15}$ Hipotensi sistemik (tekanan darah sistolik $<90 \mathrm{mmHg}$ selama 30 menit) memberikan hasil luaran yang buruk pada pasien dengan cedera kepala traumatik berat. ${ }^{15}$

Hipotensi persisten pada pasien trauma multipel adalah indikator prognostik yang buruk dan mencapai $50 \%$ kematian. Hal ini disebabkan karena perdarahan yang tidak terkontrol dan tidak adekuat resusitasi. Prinsip utama anestesi pada cedera kepala traumatik adalah untuk mempertahankan tekanan perfusi serebral (CPP) lebih dari $70 \mathrm{mmHg}$. Bila tidak ada alat monitoring tekanan intrakranial, tekanan darah sistolik $\geq$ $90 \mathrm{mmHg}$ adalah direkomendasikan, sehingga tekanan arteri rerata dapat dipertahankan. Ini tidak dapat dicapai karena kehilangan darah dan disfungsi jantung karena tamponade. Pada beberapa penelitian transfusi sel darah merah (packed red cell/PRC) yang berlebihan telah terbukti berkorelasi dengan hasil luaran pasien buruk. ${ }^{11-18}$

\section{$\mathrm{D}=$ Drugs $=$ Tatakelola Anestesi}

Hindari obat-obatan dan tehnik anestesi yang meningkatkan tekanan intrakranial, berikan obat yang mempunyai efek proteksi otak. ${ }^{7}$ Obatobatan dan tehnik anestesi yang merupakan kontraindikasi pada pasien dengan cedera otak traumatik berat adalah: premedikasi dengan narkotik, jalan napas spontan, neurolept analgesia, ketamin, $\mathrm{N}_{2} \mathrm{O}$ bila ada aerocele, halotan, anestesi spinal. Hal ini karena analgesia dapat mendepresi napas, ketamin meningkatkan ICP, $\mathrm{CMRO}_{2}$ dan mempresipitasi kejang. Keterbatasan ini bisa dipertimbangkan bila anestesi dilakukan setelah autoregulasi otak kembali (dimulai hari ke-5, dan maksimal pada hari ke-9 setelah cedera kepala traumatik). ${ }^{15}$ Obat-obatan opioid dan obat penenang dapat menyebabkan depresi pernafasan, sehingga obat-obatan ini sebaiknya dihindari dalam premedikasi. Jalur intramuskular dan subkutan harus dihindari karena absorpsi sangat tidak dapat diandalkan. Obesitas mengubah farmakokinetik sebagian besar obat-obatan. Substansi lipofilik yang tinggi seperti barbiturat dan benzodiazepin menunjukkan peningkatan volume distribusi yang signifikan pada individu obesitas dan dosis harus didasarkan pada total berat badan untuk agen lipofilik. Senyawa lipofilik yang kurang memiliki sedikit atau tidak ada perubahan volume distribusi dengan obesitas dan dosis harus didasarkan pada berat badan ideal untuk obat ini. ${ }^{7-10}$

Kami melakukan induksi anestesi dengan menguji responsnya terhadap obat-obatan dengan cara menilai reflex bulu mata, kami melakukan pemberian obat dengan cara titrasi pada saat induksi (karena pasien sudah di bawah pengaruh obat-obatan anestesi) dan pemeliharaan anestesi. Pemberian dosis propofol kontinyu disesuikan 
dengan keadaan hemodinamik pasien. Pada pasien obesitas morbid dengan trauma multipel dalam keadaan hipovolemik dan hemodinamik yang tidak stabil, seperti pada kasus kami lebih baik menggunakan narkotika (narcotic base anesthesia), sehingga dosis propofol dan relaksan otot dapat diturunkan (rumatan anestesi intravena). Hal-hal inilah yang menjadi pertimbangan kami dalam tatakelola anestesi pasien ini, saat induksi kami menggunakan: fentanyl $150 \mu \mathrm{g}(1 \mu \mathrm{g} / \mathrm{KgBB})$ titrasi, propofol $100 \mathrm{mg}( \pm 0,66 \mathrm{mg} / \mathrm{KgBB})$ titrasi, vecuronium 8 mg. Hal ini memiliki keuntungan dari stabilitas hemodinamik yang baik, tetapi kekurangannya penilaian tingkat kesadaran (Glasgow coma scale/GCS) pascabedah sulit dilakukan. Anestesi volatil untuk tehnik anestesi kombinasi (balance anesthesia) dapat ditambahkan pada pasien yang sangat stabil tanpa perdarahan berkelanjutan. Bersiaplah untuk mengubah teknik pemeliharaan kapan saja selama anestesi karena kondisi keadaan hemodinamik pasien mungkin berubah secara tiba-tiba. ${ }^{3-6,11-18}$ Pada kasus kami, karena perdarahan $\pm 200 \mathrm{cc}$, untuk pemeliharaan anestesi kami menggunakan: sevoflurane $0,8-1$ vol\% dengan aliran oksigen dan air (50:50) kombinasi syringe kontinyu: vecurronium $2 \mathrm{mg} /$ jam dan propofol $50-100 \mathrm{mg} / \mathrm{jam}$, tergantung hemodinamik pasien selama operasi (MAP $>70$ $\mathrm{mmHg}$ ). Prinsip dasar pengelolaan anestesi pada cedera kepala traumatik adalah ${ }^{3-6}$ :

- Mengoptimalkan perfusi otak dengan rumatan hemodinamik sistemik (mean arterial pressure/MAP, cerebral perfusion pressure/CPP)

- Menghindari iskemik serebral dengan melihat $\mathrm{DO}_{2}, \mathrm{PaO}_{2}, \mathrm{CPP}$, cerebral blood flow/CBF

- Menghindari tehnik dan obat yang meningkatkan ICP

Selanjutnya, teknik anestesi pilihan pada operasi bedah kepala harus mempertahankan atau hanya sedikit mengganggu autoregulasi serebral dan responsif terhadap $\mathrm{CO}_{2}$. Tehnik anestesi harus mampu menjaga relaksasi otak dan memberikan pemulihan yang cepat, sehingga dapat dilakukan penilaian hasil luaran segera setelah operasi, sebagai evaluasi awal. ${ }^{3-6}$
$\mathrm{E}=$ Environment $=\mathrm{Suhu}$

Penurunan suhu tubuh sampai $33-35^{\circ} \mathrm{C}$ mempunyai efek proteksi otak. Mekanisme proteksi termasuk penurunan kebutuhan metabolisme, eksitotoksisitas, pembentukan radikal bebas dan pembentukan edema otak. Pada model hewan coba yang dibuat mengalami iskemik, hipotermia ringan $34-36^{\circ} \mathrm{C}$ melemahkan cedera iskemik. Pada praktek klinis, kontroversi tentang efektivitas hipotermia pada cedera kepala traumatik masih berlangsung.

Penelitian multi institusi tentang hipotermia pascabedah pada pasien cedera kepala traumatik telah dihentikan oleh Safety Monitoring Board setelah penelitian pada 392 pasien. Hasilnya menunjukkan tidak ada perbedaan dalam angka kematian antara pasien dengan hipotermi dan normotermi, dan pasien dengan hipotermi mengalami lebih banyak komplikasi. Analisis subgroup menunjukkan bahwa pasien yang lebih muda ( $\leq 45$ tahun) yang hipotermi pada saat masuk ke rumah sakit dan dirancang untuk grup hipotermi bertendensi untuk mempunyai hasil luaran yang lebih baik daripada yang dirancang di group normotermi. ${ }^{15}$ Bila terapi hipotermi dipilih, diperlukan penanganan yang hati-hati untuk menghindari efek samping buruk seperti hipotensi, aritmia jantung, koagulopati dan infeksi. Rewarming harus dilakukan perlahanlahan. Pemantauan suhu dianjurkan dilakukan pada dua tempat atau lebih, yaitu: membrane timpani, nasofaring, esophagus dan darah. ${ }^{11-18}$

Tatakelola Pascabedah

Penanganan di intensive care unit/ICU masih terus berusaha memperbaiki konsekuensi fisiologis dari cedera sekunder dan kegagalan metabolik yang terkait. Rewarming aktif dilanjutkan dengan selimut penghangat udara, cairan hangat dan lingkung/ruangan keseluruhan yang hangat. ${ }^{3-6}$

Dalam sebagian besar kasus, kami tidak berniat untuk bangun dan mem-ekstubasi pasien trauma multipel pada akhir operasi. Pasien ditransfer ke ICU untuk menyelesaikan resusitasi dan optimalisasi perfusi organ akhir. Selain itu, pasien membutuhkan anagesia yang baik selama pengangkutan ke ICU atau prosedur diagnostik 
jarakjauh(CT-scan/MRI/ angiography). ${ }^{3-6}$ Perfusi harus dikembalikan ke jaringan tubuh dengan cairan resusitasi yang memadai, meminimalkan asidosis dan deficit oksigen dari metabolisme anaerobik. Bila terjadi koagulopati, harus segera dikoreksi dengan pemberian fresh frozen plasma, cryoprecipitate dan trombosit seperlunya. ${ }^{11-14}$

Parameter terukur lainnya yang telah disarankan sebagai prediktor persyaratan transfusi masif meliputi ${ }^{11-14}$ :

- Defisit BE > 6;

- Rasio normalisasi internasional $>1,5$;

- Tekanan darah sistolik $<90 \mathrm{mmHg}$ dalam trauma berat

- Tekanan darah sistolik $<110 \mathrm{mmHg}$ pada pasien trauma ringan-sedang;

- Hemoglobin < $11 \mathrm{gr} / \mathrm{dL}$;

- Suhu $<35-36{ }^{\circ} \mathrm{C}$;

- Denyut nadi radial yang lemah atau tidak ada.

Operasi ulangan diindikasikan jika ada perdarahan jelas yang sedang berlangsung atau jika sindrom kompartemen perut berkembang (bila terdapat trauma abdomen). Tindakan resusitasi dihentikan adalah $^{11-14}$ :

- Stabilitas hemodinamik, tidak ada vassopresors;

- Normokarbia, normokarbia;

- Tingkat laktat $<2 \mathrm{mmol} / \mathrm{L}$;

- Normotermia;

- Nilai faktor-faktor koagulasi dalam batas normal;

- Urin output $\geq 1 \mathrm{ml} / \mathrm{kgBB} / \mathrm{jam}$.

Waktu operasi ekstrakranial akan tergantung pada tingkat keparahan dan efek dari cedera tersebut terhadap perfusi serebral dan oksigenasi. Hipoksemia dan hipotensi merupakan penyebab utama kematian pada pasien dengan cedera kepala traumatik berat. Keterlambatan kraniotomi menyebabkan sebagian besar kematian karena cedera kepala terutama pada pasien yang mengalami hematoma subdural traumatik. Faktor-faktor ini yang menjadi pertimbangan kami dalam menentukan urutan dan jadwal operasi selanjutnya. ${ }^{11-18}$ Seperti pada kasus kami, operasi pertama yang dilakukan hanya evakusi perdarahan subdural, dekompresi kraniektomi dan pemasangan gips pada fraktur $1 / 3$ tertutup distal tibia fibula kiri. Penjadwalan operasi definitif (hari ke-5 sampai ke-10 setelah trauma ("window of opportunity"). Hal ini ditentukan oleh peningkatan status fisiologis pasien dan membutuhkan lebih dari satu tindakan bedah. Indeks berikut ini sering digunakan untuk memandu operasi ulang: defisit base excess (BE) $>$ - $4 \mathrm{mmol} / \mathrm{L}$, laktat $<2,5 \mathrm{mmol} / \mathrm{L}$, suhu inti $>35$ ${ }^{\circ} \mathrm{C}$ dan INR $<1,25 .{ }^{11-14}$

Pada tahap ini, para ahli bedah dapat melakukan tindakan seperti: anastomosis dibentuk, stoma dibesarkan dengan rekonstruksi saluran pencernaan, perbaikan vaskular yang dilakukan, penutupan fasia abdomen, fiksasi tulang internal, penutupan luka terbuka. Para ahli anestesi/intensivist harus mempertimbangkan trakeostomi dalam kasus ventilasi mekanis yang berkepanjangan atau bila GCS $<8$ (untuk memudahkan pengelolaan jalan napas), dan penempatan jejunal tube (untuk nutrisi pasien). ${ }^{11-14}$ Pembedahan rekonstruksi sekunder (disarankan $>3$ minggu setelah trauma). Pada tahap ini, setelah resolusi edema dan imunosupresi, intervensi rekonstruktif dapat dilakukan seperti: rekonstruksi ligamentum, penggantian prostesis artikulasi, rekonstruksi syaraf, rekonstruksi tulang setelah kraniotomi. ${ }^{11-14}$

\section{Simpulan}

Tatakelola anestesi pasien trauma multipel dengan penyulit obesitas morbid sangat kompleks, membutuhkan kolaborasi yang baik dengan ahli bedah trauma dan anggota tim trauma lainnya. Untuk meminimalkan risiko anestesi pada korban trauma, para ahli anestesi harus mengetahui sebanyak mungkin tentang lesi traumatik dan mengetahui prosedur bedah yang tepat dan risiko terkait. Rencana anestesi harus mempertimbangkan status resusitasi dan riwayat penyakit penyerta lain yang diderita pasien, seperti obesitas, alergi, hipertensi, sehingga dapat memberikan obat anestesi optimal dan perangkat pemantauan yang tepat.

Pengelolaan cairan memberikan tantangan tersendiri karena perubahan status volume yang cepat dan tidak dapat diprediksi serta resusitasi 
pra-operasi yang tidak lengkap. Apalagi pada pasien obesitas morbid, yang biasanya disertai kelainan pembesaran jantung. Para ahli anestesi sangat penting dalam mengawasi proses resusitasi cairan untuk mengoptimalkan hemostasis dan kelangsungan hidup jangka panjang. Pemasangan CVC untuk pengukuran status volume pasien sangat berperan pada kasus ini. Pemasangan artery line pun bila memungkinkan sangat diperlukan untuk mengantisipasi gejolak hemodinamik yang mungkin terjadi. Hal ini menjadi kekurangan pada kasus yang kami laporkan, dikarenakan keadaan pasien yang kami nilai masih dalam kondisi stabil dan keterbatasan waktu saat operasi dilakukan. Peran penting lainnya dari anestesiologis adalah pencegahan cedera sekunder yang disebabkan oleh syok berulang atau resusitasi tidak tepat.

\section{Daftar Pustaka}

1. Bansal T, Hooda S. Obesity: anesthetic implications and consideration-a review. Cumhuriyet Med J 2014; 36: 409-14.

2. Bansal T, Kumar P, Hooda S. Regional anaesthesia-still a comfortable choice in morbidly obese parturient. Colombian Journal of Anaesthesiology 2013; 41: 302-5.

3. Turner J, Nicholl J, Webber L, Cox H, Dixon $\mathrm{S}$, Yates D. A randomized controlled trial of prehospital intravenous fluid replacement therapy in serious trauma. Health Technology Assessment 2000, 4: 1-57.

4. Martinuc C, Doborat GH. Polytrauma with severe traumatic brain injury. Case report. Romanian Neurosurgery 2010; 17(1):108-13.

5. Gunetilleke B. A patient with polytrauma including a severe head injury, haemathorax and cardiac tamponade. Srilankan Journal of Anaesthesiology 2009; 17 (2): 80-6.

6. Prabhu A, Matta B. Anaesthesia for extracranial surgery in patients with traumatic brain injury. Continuing Education in Anaesthesia. Critical Care and Pain 2004: 4 (5): 156-9.
7. Murphy PG. Obesity. Dalam: Hemmings HC, Jr, Hopkins PM, editor. Foundations of Anaesthesia, Basic and Clinical Sciences. London: Mosby, 2000; 703-11.

8. Adams JP, Murphy PG. Obesity in anaesthesia and intensive care. Br J Anaesth 2000; 85: 91-108.

9. Servin F, Farinotti R, Haberer JP, Desmonts JM. Propofol infusion for maintenance of anesthesia in morbidly obese patients receiving nitrousoxide. A clinical and pharmacokinetic study. Anesthesiology 1993; 78: 657-65.

10. Smith HL, Meldrum DJ, Brennan LJ. Childhood obesity: a challenge for the anaesthetist? Paediatr Anaesth 2002; 12: $750-61$.

11. Ganie FA, Lone H, Lone GN, Wani ML, Singh S, Dar AM, dkk. Lung contusion: a clinic pathological entity with npredictable clinical course. Bull Emerg Trauma 2013; 1 (1):7-16.

12. Hasan WMNM, Nasir YH, Zaini RHM, Shukeri WFWH. Target-controlled infusion propofol versus sevoflurane anesthesia for emergency traumatic brain surgery: comparasion of outcomes. Malays J Med Sci 2017; 24 (5):73-82.

13. Ortega-Gonzalez MDC. Anesthesia for trauma patients. S Afr Fam Pract 2012; 54 (3): S2-6.

14. Mc Cunn M, Gordon E, Scott TH. Anesthetic concerns in trauma victims requiring operative intervention: the patient too sick to anesthetize. Anesthesiology Clinic. 2010; 28 (1): 97-116.

15. Bisri DY, Bisri T. Anestesia pada pasien dengan cedera otak tramatik. Dalam: Bisri DY, Bisri T, editor. Pengelolaan Perioperatif Cedera Otak Traumatik, edisi ke-1, Bandung: Fakultas Kedokteran Universitas Padjajaran; 
$2018,87-128$.

16. Ortega-Gonzalez MDC, Monzon-Torres BI. Value and impact of massive blood transfusion protocols in the management of trauma patients. S Afr J Anaesthesiol Anag. 2011;17(4): 282-85.

17. Moore EE, Burch JM, Franciose R, Offner P,
Biffl W. Staged physiologic restoration and damage control surgery. World J Surg 1998, 22(12): 1184-90.

18. Cobanoglu U, Melek M, Edirne Y. Diagnosis of pulmonary contusion by CXR is associated with higher morbidity and mortality rates. Indian J Thorac Cardiovasc Surg 2010; 26: 24-9. 